\title{
Glimatically induced retreat and collapse of northern Larsen Ice Shelf, Antarctic Peninsula
}

\author{
Helmut Rott, ${ }^{1}$ Wolfgang Rack, ${ }^{1}$ Thomas Nagler, ${ }^{1}$ Pedro Skvarca ${ }^{2}$ \\ ${ }^{1}$ Institute of Meteorology and Geophysics, University of Innsbruck, A-6020 Innsbruck, Austria \\ ${ }^{2}$ Instituto Antártico Argentino, Cerrito 1248, 1010 Buenos Aires, Argentina
}

\begin{abstract}
The areal changes of the northern Larsen Ice Shelf (LIS), Antarctic Peninsula, between March 1986 and March 1997 have been analyzed, based on synthetic aperture radar images of the European remote-sensing satellites ERS-1 and ERS-2 and on Landsat images. This analysis is complemented by data on ice motion and surface mass balance which have been obtained during several field campaigns since the early 1980s. After a period of retreat, coinciding with atmospheric warming and with decreasing net accumulation at the surface due to melt losses, the two northernmost sections of LIS disintegrated almost completely within a few days in January 1995. Recent observations of the ice-shelf section north of Jason Peninsula, which is presently the northernmost section of LIS, show increased summer melt and intensification of the rifting processes, probably causing accelerated retreat of this section in the near future. The retreat and the disintegration event of LIS indicate high sensitivity of ice shelves to prolonged perturbations of the mass balance.
\end{abstract}

\section{INTRODUCTION}

The Larsen Ice Shelf (LIS) extends along the eastern side of the Antarctic Peninsula from $65^{\circ}$ to $74^{\circ} \mathrm{S}$. In the late 1980 s, LIS covered a total area of about $95000 \mathrm{~km}^{2}$ (Frolich, 1992). Between 1975 and 1986-89 the ice-shelf area decreased by a total of about $9300 \mathrm{~km}^{2}$, primarily due to calving of two large icebergs between Jason Peninsula $\left(66^{\circ} \mathrm{S}\right)$ and Gipps Ice Rise $\left(69^{\circ} \mathrm{S}\right)$ (Skvarca, 1994). We report on changes of the sections of LIS north of Jason Peninsula since 1986 (Fig. 1). The part of LIS north of Robertson Island has retreated constantly since the 1940s (Doake, 1982; Skvarca, 1993). The retreat accelerated after 1975, and finally the two remaining sections north of Robertson Island collapsed early in 1995 (Rott and others, 1996). Since the collapse, increased attention has been focused on the section between Seal Nunataks and Jason Peninsula which is presently the northernmost section of LIS.

As a baseline for the analysis of areal changes, we selected cloud-free Landsat multispectral scanner (MSS) images acquired on 1 March 1986. Further Landsat images, covering parts of the investigation area, are available for 1988 and 1989. Improved temporal coverage was possible after the launch of the European remote-sensing satellites ERS-1 in July 1991 and ERS-2 in April 1995. The ERS synthetic aperture radar (SAR) images of the Antarctic Peninsula were acquired at the German receiving station near the Chilean base O'Higgins. Because this station operates on a campaign basis, SAR images are available only for two to three periods of 5 weeks each year. Fortunately, the station was operating during the disintegration event in early 1995. Field observations on ice motion, surface mass balance, snow and ice morphology and ice thickness were carried out on the ice-shelf sections north and south of the Seal Nunataks several times between the early 1980s and October 1996.

\section{OVERALL AREAL CHANGES, 1986-97}

The analysis of ice-shelf areas was based on satellite images in the Universal Transverse Mercator (UTM) projection. The ERS SAR images were obtained in geocoded ellipsoid corrected (GEC) format with nominal spatial resolution of $30 \mathrm{~m} \times 30 \mathrm{~m}$ and nominal absolute location accuracy of about $100 \mathrm{~m}$. We used geodetic field data of stable features such as boundaries of nunataks, measured with differential GPS, to improve the positional accuracy. However, due to the lack of accurate elevation data, we were unable to correct for the terrain-induced distortions. For this reason, high geodetic accuracy can be achieved with the SAR images only on the relatively flat floating parts. The extent of the grounded parts (Table l) was determined from topographic maps of the British Antarctic Survey, supplemented by Landsat images. Because of the large scale of these maps (1:250000 and 1:500000), mapping accuracies of the grounded parts are not as high as for the ice shelves which were mapped from the high-resolution satellite images.

Figure 1 shows ERS SAR image mosaics of northern LIS on 23 August 1993 and 2 March 1997. In both images the backscattering coefficient, $\sigma^{\circ}$, on the ice shelf is comparatively high due to volume scattering from the frozen firn and ice, with $\sigma^{\circ}$ values around $-2 \mathrm{~dB}$ in the August images. In the image from $2 \mathrm{March}, \sigma^{\circ}$ is lower by a few $\mathrm{dB}$ because snow and ice were not yet completely refrozen. Drainage features and melt lakes are still visible below the surface. In the summer images with wet snow, $\sigma^{\circ}$ values are typically around $-15 \mathrm{~dB}$ (Fig. 4).

According to the flow characteristics, the ice shelf north of Jason Peninsula can be separated into five sections. At the sections in the Prince Gustav Channel (PG) and in the Larsen Inlet (LI) the size of the grounded part of the catchment clearly surpassed that of the floating part by 1986 . At the sec- 

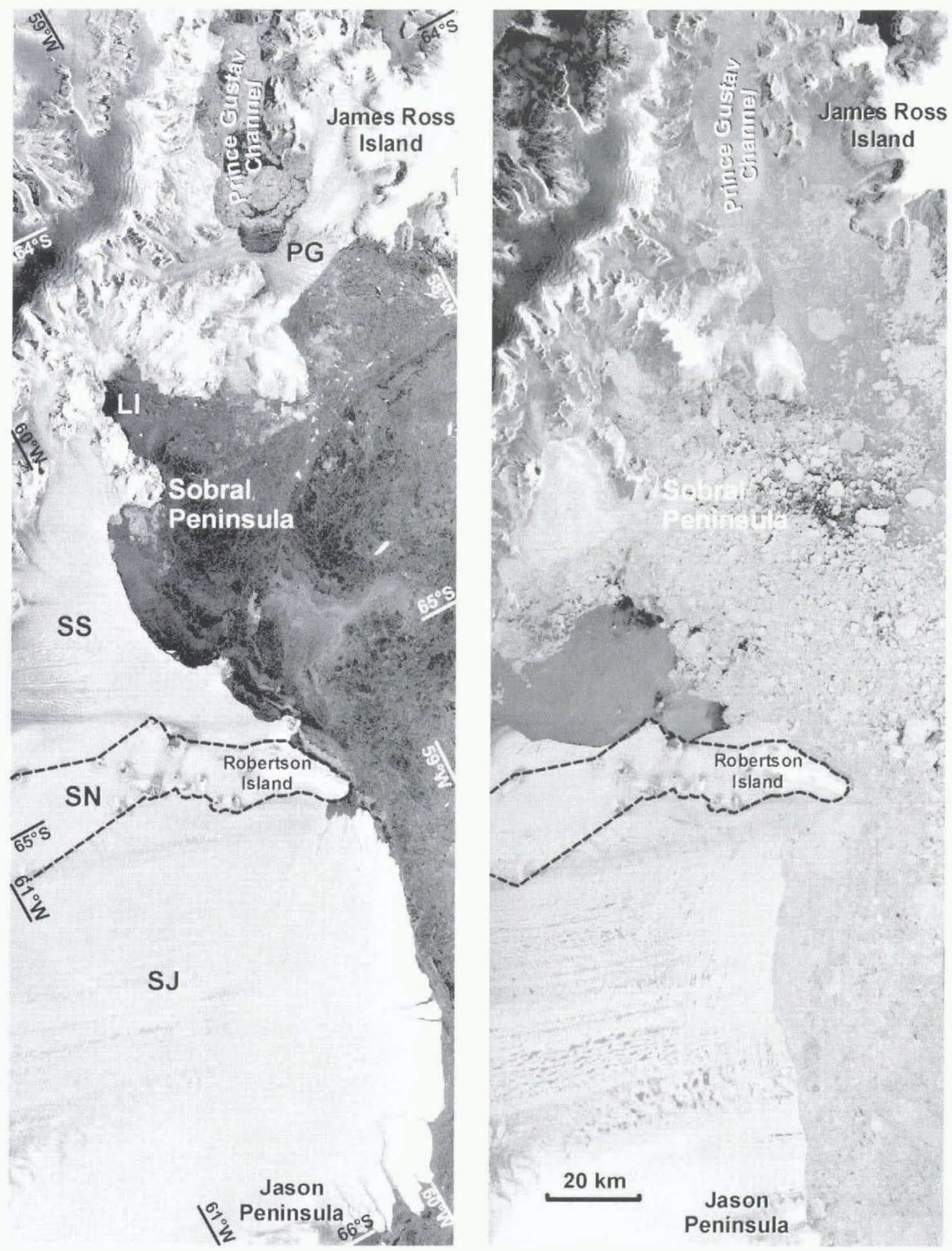

Fig. 1. ERS-1 SAR image mosaic from 26 August 1993 (left) and ERS-2 SAR image mosaic from 2 March 1997 (right), showing northern LIS. Ice-shelf sections: PG, Prince Gustav Channel; LI, Larsen Inlet; SS, Sobral Peninsula to Seal Nunataks; SN, around Seal Nunataks; Ş̃. Seal Nunataks to Jason Peninsula. C ESA 1993, 1997.

tion between Sobral Peninsula and Seal Nunataks (SS) the grounded part was slightly larger in 1986, whereas at the section between Seal Nunataks and Jason Peninsula (SJ) the grounded part was about $30 \%$ smaller than the floating part. Because the accumulation on the glaciers of the peninsula is significantly larger than on the ice shelves (Frolich, 1992), it can be concluded that, for the sections PG, LI, SS and SJ, the mass contribution from the grounded part significantly exceeded the mass accumulated in situ. This is different for the ice shelf between the Seal Nunataks (SN) which shows very little motion. This part, which is separated from the ocean by the ice-covered Robertson Island and nourished by local accumulation, showed little areal change.

The three northernmost sections (PG, LI, SS) have disintegrated almost completely within the last few years. The final disintegration of sections PG and SS took place in early 1995, coincident with a major calving event at section SJ. The ice shelf in Larsen Inlet (LI) disintegrated between March 1986 and November 1989, as documented by means of Landsat images (Skvarca, 1993). Below, we present further information on the recent changes to sections $\mathrm{PG}$, SS and SJ. 


\section{THE ICE SHELF IN PRINCE GUSTAV GHANNEL}

After retreat since the last century (Cooper, 1997), the ice shelf that occupied parts of Prince Gustav Channel (section PG) was separated from the main ice shelf in 1957 or 1958 (Doake, 1982). The southern ice front retreated by about $15 \mathrm{~km}$ between 1958 and 1969, was almost stationary between 1969 and 1986 (Skvarca, 1993) and retreated by another $5 \mathrm{~km}$ between March 1986 and August 1993. The northern ice front was almost stationary between 1957 and 1986. Figure 2 shows a SAR image from 2 July 1992. Based on the analysis of flowlines, surface morphology, and ice motion in satellite imagery we discriminate five distinct zones on the ice shelf $(\mathrm{A}-\mathrm{E})$. Complex fractures characterise the boundaries between these zones. Fields of ice motion were determined by digital correlation of ERS SAR amplitude images and Landsat TM images over time intervals of about lyear.

Zone $\mathrm{A}$ in the north and zone $\mathrm{E}$ in the southwest received input from comparatively small catchments on the eastern slope of the peninsula as the motion analysis shows. In situ accumulation possibly also played a role (Reece, 1950). The most prominent flow features are visible in zone $B$ which was nourished by an outlet glacier draining a catchment of $710 \mathrm{~km}^{2}$ and originating at the Detroit Plateau. The two main glaciers contributing to this outlet are Sjøgren and Boydell Glaciers. The northern arm of zone B extended eastwards towards Persson Island, and before 1986 touched the coast near Cape Obelisk. Through the southern arm of zone $\mathrm{B}$, ice from the main outlet was transported towards the southern ice edge. The inflow to zone C came from James Ross Island. The contributing grounded catchment area is estimated at $530 \mathrm{~km}^{2}$, with uncertainties due to difficulties in identification of the ice divides on the ice cap. Zone D was an almost stagnant transition zone between ice from the peninsula and from James Ross Island. It was made up

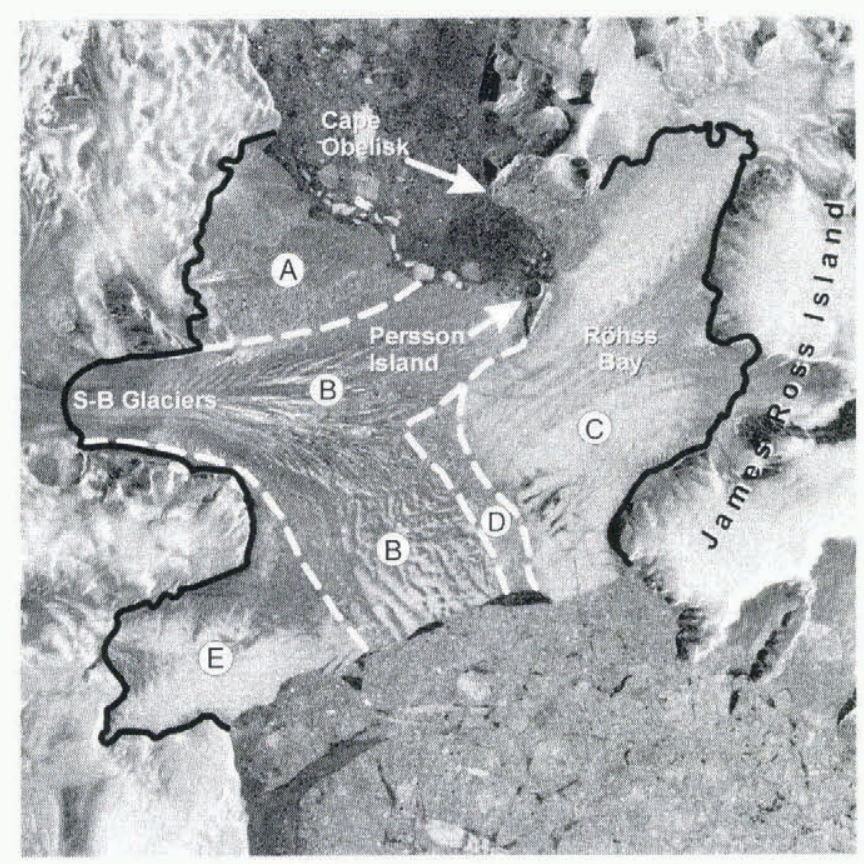

Fig. 2. ERS-1 SAR image from 2 July 1992 showing the section of LIS in Prince Gustav Channel (PG). A-E, ice-shelf zones described in the text. Grounding line in black. S-B,Sjogren and Boydell Glaciers. (C) ESA 1992.
Table 1. Areal extent of grounded catchmenls and of floating ice for the five northern sections of LIS $\left(\mathrm{km}^{2}\right)$ (locations shown in Fig. 1)

\begin{tabular}{lrrr}
\hline Section & Grounded & \multicolumn{2}{c}{ Floating } \\
& & I. March 1986 & /. March 1997 \\
& & & \\
\hline PG & 1580 & 984 & 147 \\
LI & 780 & 399 & 20 \\
SS & 2640 & 2488 & 251 \\
SN & 283 & 789 & 781 \\
SJ & 8500 & 11560 & 9397 \\
Total & 13783 & 16220 & 10596 \\
& & & \\
\hline
\end{tabular}

of a mixture of icebergs detached from zones B and C, as well as of snow accumulated on fast ice between the icebergs.

For section PG no mass-balance data are available. SAR images, available since 1992, show intense summer melt. Extrapolating from surface balance data in the southern sections, it is concluded that, at least during the 1990s, the loss of mass due to summer ablation exceeded the annual accumulation.

Figure 3 shows an ERS SAR image from 30 January 1995 and the ice-shelf boundaries at selected dates between 1 March 1986 and 2 March 1997 which were mapped from SAR and Landsat images. The ice-shelf areas for different dates are listed in Table 2. The final retreat started in the north where a major polynya was already visible near Cape Obelisk in the MSS image of 1986. When the ice became detached from the coast, the constraining forces in the northeastern part of zone B were reduced. The changes of the strain field resulted in a short-term advance of the ice front of $350 \mathrm{~m}$ between 29 February 1988 (ice-shelf area $845 \mathrm{~km}^{2}$ ) and 5 November $1989\left(852 \mathrm{~km}^{2}\right)$. The main part of zone A

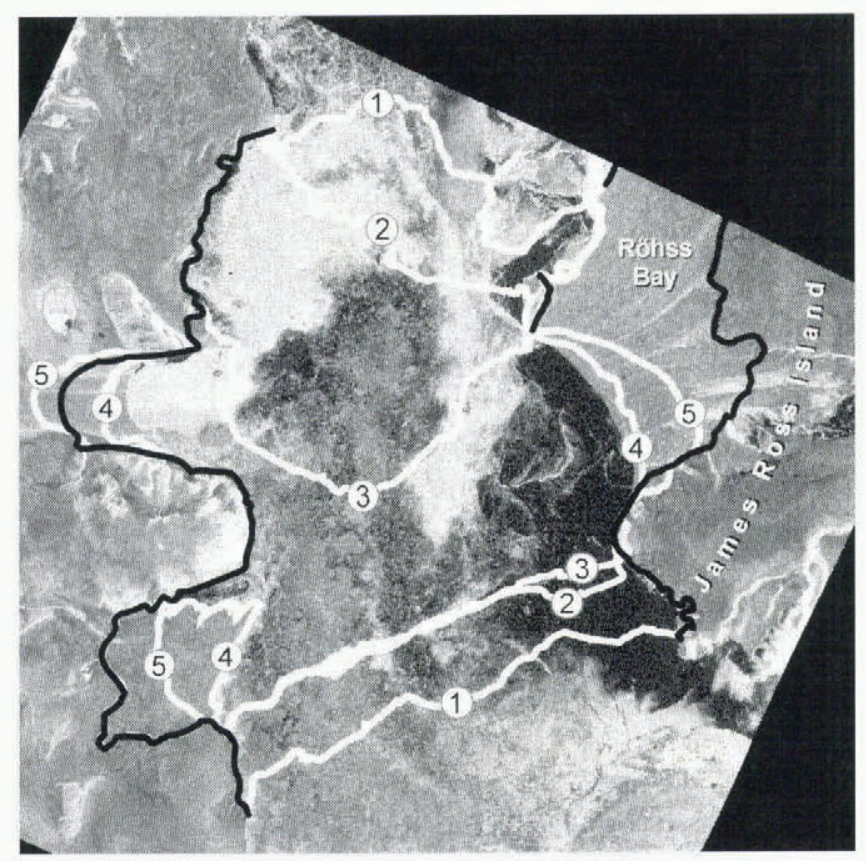

Fig. 3. ERS-2 SAR image of 30 January 1995 showing the same area as Figure 2. Ice-front positions: (1) 1 March 1986, (2) 2 July 1992, (3) 26 August 1993, (4) 8 March 1995, (5) 2 March 1997. (c) ESA 199.5. 
Table 2. Areal extent $\left(\mathrm{km}^{2}\right)$ of LIS sections $P G$, SS and SF, derived from ERS SAR images at different dates between 2 July 1992 and 2 March 1997

\begin{tabular}{|c|c|c|c|c|c|}
\hline Section & 2 July 1992 & $\begin{array}{c}16 \text { February } \\
1993\end{array}$ & $\begin{array}{c}26 \text { August } \\
1993\end{array}$ & $\begin{array}{c}28 \text { January } \\
1995\end{array}$ & $\begin{array}{l}30 \text { January } \\
1995\end{array}$ \\
\hline PG & 762 & 527 & 528 & n.a. & 224 \\
\hline SS & 2244 & 2045 & 2027 & 1957 & 1101 \\
\hline SJ & 11775 & n.a. & 11770 & n.a. & 9496 \\
\hline Section & $\begin{array}{l}8 \text { March } \\
1995\end{array}$ & $\begin{array}{c}28 \text { October } \\
1995\end{array}$ & $\begin{array}{c}29 \text { February } \\
1996\end{array}$ & $\begin{array}{c}\text { 1. November } \\
1996\end{array}$ & $\begin{array}{l}2 \text { March } \\
1997\end{array}$ \\
\hline PG & 211 & 204 & 175 & 165 & 147 \\
\hline SS & 368 & 268 & 251 & 253 & 251 \\
\hline SJ & 9496 & 9501 & 9483 & 9391 & 9397 \\
\hline
\end{tabular}

n.a., not available (section not fully covered by SAR image).

and the northern part of zone B broke away during summer 1992-93, whereas zones C, D and E and the southern arm of zone B show a similar extent in the SAR images of July 1992 and February 1993. In summer 1994-95 the first SAR images became available on 28 January 1995, covering only the western part of section PG, and on 30 January 1995. Both images show that the ice shelf had disintegrated, leaving only two small parts on the west coast and another part in Röhss Bay. Since January 1995 the areas of these remnant parts decreased further. In summer 1996-97 the Sjøgren and Boydell outlet glaciers had already retreated beyond the grounding line.

\section{THE SECTION BETWEEN SOBRAL PENINSULA AND SEAL NUNATAKS}

The ice-shelf section between Sobral Peninsula and Seal Nunataks (section SS) collapsed in January 1995 (Rott and others, 1996). The two main tributaries to this section were Drygalski Glacier, with a grounded catchment area of $1015 \mathrm{~km}^{2}$, and the ice stream which is nourished by Dinsmoor, Bombardier and Edgeworth (D-B-E) Glaciers, with a grounded catchment of $676 \mathrm{~km}^{2}$. Flowlines are visible in the ERS-1 SAR image of 12 January 1993 (Fig. 4). The ice downstream of D-B-E glaciers, where the ice flow turned by $90^{\circ}$ and diverged laterally, played a critical role in the rapid collapse.

Ice motion was measured in November 1991 along a transect between Sobral Peninsula and Larsen Nunatak. The ice velocity ranged from $0.51 \mathrm{~m} \mathrm{~d}^{-1}$ at stake Pl $2.5 \mathrm{~km}$ north of Larsen Nunatak to $0.57 \mathrm{~m} \mathrm{~d}^{-1}$ at $\mathrm{P} 7$ near the centre of the transect. In November 1994 the southern half of the transect was remeasured; the northern part had been lost the previous summer due to calving. The velocities ranged from $0.63 \mathrm{~m} \mathrm{~d}^{-1}$ at $\mathrm{Pl}$ to $0.68 \mathrm{~m} \mathrm{~d}^{-1}$ at $\mathrm{P} 7$, an increase of about $20 \%$ in comparison to 1991 . Two wooden stakes near P7, placed in November 1984, were remeasured in November 1994. The average velocities for the 10 year period corresponded to the velocities measured in November 1994. Ice thickness, measured along this profile in 1991 by means of monopulse radar, ranged from $180 \mathrm{~m}$ at stake $\mathrm{Pl}$ to values of 210-240 $\mathrm{m}$ in the central and northern part.

Between 1975 and 1986 the ice front between Sobral

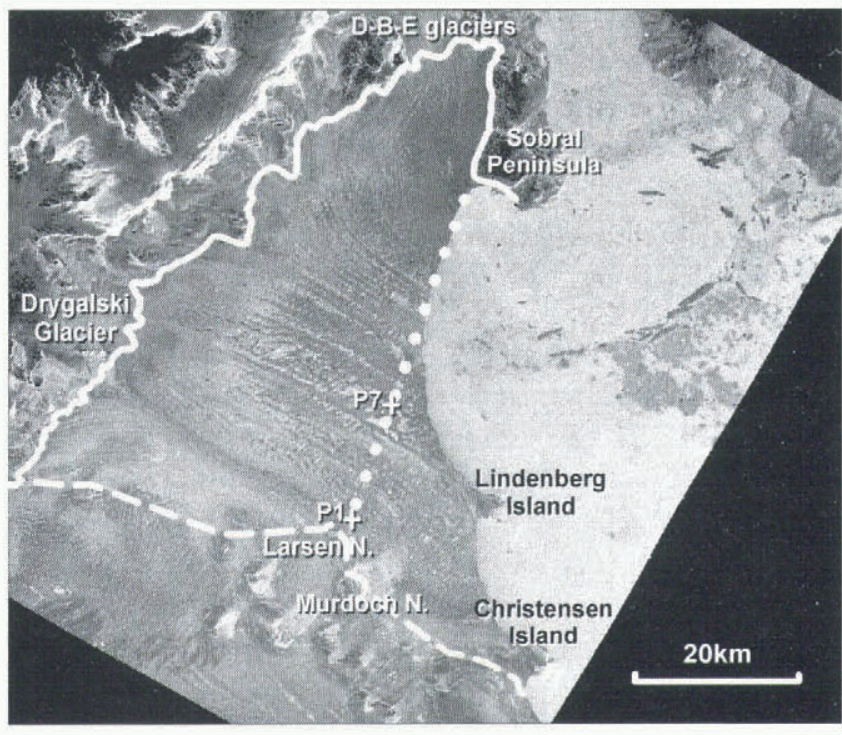

Fig. 4. ERS-1 SAR image of the section of LIS between Sobral Peninsula and Seal Nunataks (section SS) from 12 January 1993. Dotted line: transect between Larsen Nunatak and Sobral Peninsula. (C) ESA 1993.

Peninsula and Lindenberg Island retreated at an average rate of about $1 \mathrm{~km} \mathrm{a}^{-1}$ (Skvarca, 1993). After 1986 the retreat of the front close to Sobral Peninsula accelerated (Fig. 5). In the southern part, Lindenberg Island as a pinning point delayed the retreat of the front until December 1992. In the warm summer $1992-93\left(2.2^{\circ} \mathrm{C}\right.$ above the 27 year average at the station Marambio), $209 \mathrm{~km}^{2}$ of ice-shelf area were lost between Lindenberg Island and Sobral Peninsula within 10 weeks (Rott and others, 1995). Due to this retreat, the ice close to Lindenberg Island became aligned approximately parallel to the flowlines. This triggered longitudinal rifting in addition to the already existing rifts which were aligned approximately normal to the flow direction. The position of

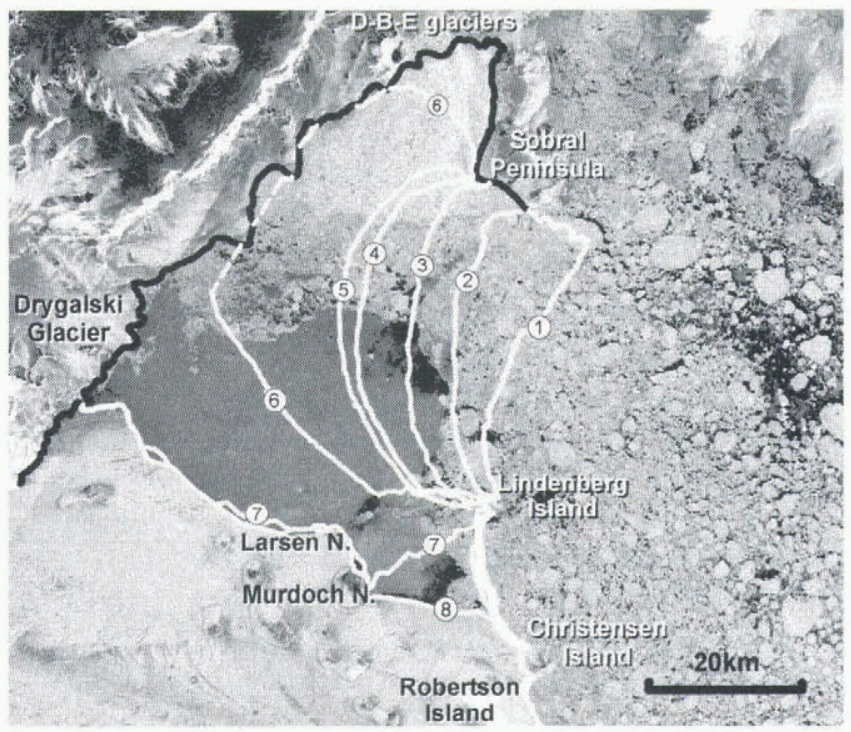

Fig. 5. ERS-2 SAR image of the region around Seal Nunataks from 2 March 1997. Ice-front positions: (1) 1 March 1986, (2) 2 July 1992, (3) 26 August 1993, (4) 25 fanuary 1995, (5) 28 fanuary 1995, (6) 30 January 1995, (7) 8 March 1995, (8) 1 November 1996. (C) ESA 1997. 
the ice front to the south of Lindenberg Island was stable between 1986 and the collapse in 1995.

During the comparatively cool summer $1993-94\left(0.3^{\circ} \mathrm{C}\right.$ below average) the retreat slowed down but the fracturing process continued, as became evident during the field campaign in October-November 1994. During the previous field campaign, in October-November 1991, the ice-shelf surface was flat with no distinct rifts and few crevasses. Three years later the surface showed gentle, large-scale undulations at kilometre scales. Major crevasses and rifts of several kilometres in length (up to $15 \mathrm{~km}$ ) extended approximately parallel to the ice front. Most heavily crevassed were the areas close to the ice front and the ice downstream of the D-B-E glaciers. Some of the rifts separated plates which differed in surface height by several metres, implying that the fractures cut completely through the ice. We had the impression that some sections had already fallen apart, but cold temperatures, which predominated during October and November 1994, and a dense cover of fast ice extending many kilometres seawards, held the fractured parts together.

The section SS finally collapsed during a period of intense northwesterly winds and high temperatures in late January 1995. Details of the collapse are documented by ERS-1 SAR images from $0413 \mathrm{~h}$ on 25 January, $0408 \mathrm{~h}$ on 28 January, and $1246 \mathrm{~h}$ on 30 January (Rott and others, 1996). Almost all of the ice to the north of the Lindenberg Island-Drygalski Glacier line broke into comparatively small icebergs and drifted away during the short period 28-30 January. Until 2 February most of the remaining ice north of the Seal Nunataks disintegrated, as known from a SAR image which covered the southern part of section SS, and from reports of the crew of Matienzo station on Larsen Nunatak. The ice-front position was already similar to that of 8 March 1995 (Fig. 5) when the next SAR image was acquired. The remnant area covered $368 \mathrm{~km}^{2}$, divided into three parts located in the bay to the west of Sobral Peninsula, to the south of Drygalski Glacier, and in triangular form between Murdoch Nunatak, Lindenberg Island and Robertson Island. The latter part disappeared almost completely during 1995.

\section{THE SECTION BETWEEN SEAL NUNATAKS AND JASON PENINSULA}

The main tributaries to the section between Seal Nunataks and Jason Peninsula (section SJ) are Hectoria and Evans Glaciers in the north, Crane Glacier in the centre, and Leppard Glacier in the south (Fig. 6). The total grounded part of the catchment has an area of about $8500 \mathrm{~km}^{2}$, including $750 \mathrm{~km}^{2}$ on Jason Peninsula. Ice motion and accumulation have been measured during several field campaigns since the early 1980 s along a transect from Gray Nunatak in the north to Lisignoli Nunatak at Jason Peninsula in the south (Fig. 6). The ice thickness increases along the transect from $200 \mathrm{~m}$ at stake Sl, $13.7 \mathrm{~km}$ distant from Gray Nunatak, to a maximum of $275 \mathrm{~m}$ measured at stake S16, $25 \mathrm{~km}$ north of Lisignoli Nunatak. The mean ice motion at stake S8 during the period 1984-94 was $1.05 \mathrm{~m} \mathrm{~d}^{-1}$, the maximum value in this transect. Between November 1994 and 1996 the mean velocity at the same point increased to $1.21 \mathrm{~m} \mathrm{~d}^{-1}$. Increases of velocity of $10-20 \%$ were also observed at the other stakes.

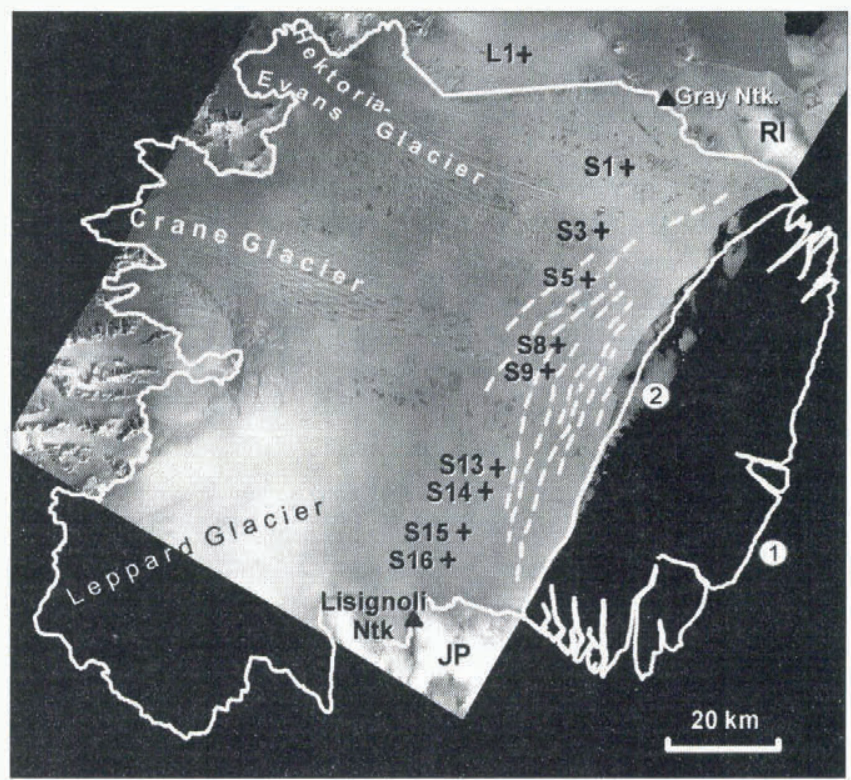

Fig. 6. ERS-2 SAR image of the section Sf between Seal Nunataks and Jason Peninsula (JP) from 1 November 1996. Ice front on (1) 26 August 1993 and (2) 8 March 1995. S1-S16, selected stakes along the transect between Gray Nunatak and Lisignoli Nunatak; Ll, stakes near Pedersen Nunatak; RI, Robertson Island. Dashed lines are major rifts. (C) ESA 1997.

This increase is at least partly attributed to the opening of major rifts, tens of metres wide, to the west of the transect.

The ice front between Robertson Island and Jason Peninsula showed a comparatively constant seaward advance between 1975 and 1992 with a total displacement of 5-6 km. Between August 1992 and 25 January 1995 the central and southern part of the front advanced further, but a small inlet formed in the rifted zone close to Robertson Island. A major rift of about $25 \mathrm{~km}$ in length, corresponding to the later calving front, was already visible in the SAR image from July 1992 south of Robertson Island. Additional rifts were formed further inland after 1992, as evident from the SAR images, as well as from the field campaigns in 1994 and 1996.

An ERS-1 SAR image is available from 25 January 1995 covering the central and northern part of section SJ. Though in this image the rifts near Robertson Island are more pronounced than in the 1993 images, there is not yet any sign of calving. The next full coverage is available from 30 January 1995, showing that the ice-shelf area had decreased by $2274 \mathrm{~km}^{2}$. Almost all of this ice was lost between 25 and 30 January 1995 in the form of a large iceberg $1720 \mathrm{~km}^{2}$ in area and many small icebergs. Though major calving losses after periods of ice-front advance are characteristic for the multi-year mass-balance cycle of ice shelves, the temporal coincidence with the disintegration further north indicates major changes in the ice dynamics of the whole region.

During the period from the calving in 1995 until March 1997 the southern part of the ice front advanced 400-800 m, whereas the northern part retreated by distances of 1$3.5 \mathrm{~km}$. In the zone up to $25 \mathrm{~km}$ inland from the ice front, the number and size of rifts has increased during the last 2 years, which indicates that further retreat is likely during the coming years. 


\section{MASS BALANCE: CLIMATE IMPLICATIONS}

The temporal change of total mass $\dot{M}$ of an ice shelf covering an area $A$ is determined by $\dot{b}_{\mathrm{s}}$ and $\dot{b}_{\mathrm{b}}$, the masses per unit area and time added or removed (the specific mass balance) at the surface and the bottom, respectively, by $\dot{M}_{\mathrm{g}}$ the rate of ice supply from grounded areas, and by $\dot{M}_{\mathrm{c}}$, the calving rate:

$$
\dot{M}=\int_{A} \dot{b}_{\mathrm{s}} \mathrm{d} A+\int_{A} \dot{b}_{\mathrm{b}} \mathrm{d} A+\dot{M}_{\mathrm{g}}+\dot{M}_{\mathrm{c}} .
$$

For the study area, no information is available on bottom melt and on ice supply from grounded areas. For the stagnant section SN it can be concluded that bottom melt was insignificant, because otherwise the comparatively small surface accumulation could not have maintained the ice shelf. Prior to the disintegration event in 1995 this section had no boundary towards the open ocean because it is confined by Robertson Island in the east. Bottom melt has probably been of more relevance for other sections. In particular, increased melting would be expected close to the seaward front due to tidal pumping (Jacobs and others, 1992). Thus the ice-front retreat north of the Seal Nunataks probably also caused changes in the mass flux at the ice-shelf bottom.

Calving rates can be estimated from satellite images, at least for the last 10 years. The progressive retreat of the ice front for the sections north of the Seal Nunataks is a clear indication of negative mass balance. For section SJ almost all of the ice export took place during the calving event in January 1995. In order to replace this ice, undisturbed advance for about 60 years would be required. The recent intensification of the fracturing process and the ongoing retreat of the ice front near Robertson Island suggest that this section is no longer in balance.

Information on surface mass balance is available for a few locations on sections SS, SN and SJ. The net mass balance at the surface results from the difference between snow accumulation and surface runoff due to summer melt. As seen on satellite imagery, during recent summers, the ice-shelf surfaces were covered by extensive lakes and drainage channels. Some fraction of the meltwater is lost to the sea through crevasses and moulins, and the rest refreezes in situ. The temporal changes of the snow surface height $(\Delta \mathrm{SH})$ were measured at stakes and are specified in $\mathrm{cm} \mathrm{a}^{-1}$ relating to the bottom of the stakes. Information on density and structure was obtained from snow pits and ice cores. During the field campaigns in 1994 and 1996 the snow and ice conditions were similar. Ice with densities of around $800 \mathrm{~kg} \mathrm{~m}^{-3}$ was covered by refrozen snow with coarse crystals and by fine-grained winter snow of a total depth around $60 \mathrm{~cm}$. This enables the estimation of the net balance $b_{\mathrm{n}}$ directly from $\Delta \mathrm{SH}$. Interannual differences in snow and ice stratigraphy may result in errors for estimating $b_{\mathrm{n}}$ from
$\Delta \mathrm{SH}$. However, over multi-year periods these differences play a minor role.

On section SS, two stakes which had been placed in 1984 were remeasured in 1994, showing a mean value for $\Delta \mathrm{SH}$ of $+9 \mathrm{~cm} \mathrm{a}^{-1}$ which implies a slightly positive surface balance for the 10 year period. On section SN, five stakes had been placed in 1978 about $10 \mathrm{~km}$ from Pedersen Nunatak (L1 in Fig. 6). The following values were measured for $\Delta \mathrm{SH}$ : $+26 \mathrm{~cm} \mathrm{a}^{-1}$ for the period 1978-88; $-3 \mathrm{~cm} \mathrm{a}^{-1}$ for 1988-94; $-22 \mathrm{~cm} \mathrm{a}^{-1}$ for 1994-96. More detailed temporal information is available for section SJ (Table 3 ). Comparatively high accumulation was observed for the period 1982-88, whereas $\Delta \mathrm{SH}$ became negative during the 1990s. The south-north decrease of $b_{\mathrm{n}}$ is evident.

The surface balance is primarily affected by the summer melt conditions, as confirmed by comparison with the air temperatures. Summer temperatures are available for the station Matienzo on Larsen Nunatak for the period 196385 (with some gaps). The mean summer temperatures at Marambio, situated $180 \mathrm{~km}$ northeast of Larsen Nunatak, differ by only $0.1^{\circ} \mathrm{C}$. Because for Marambio meteorological data are available from 1970 to the present, our discussion is based on these data. The record shows increasing mean summer (December-February) temperatures: $\left\langle T_{\mathrm{s}}\right\rangle=$ $-2.4^{\circ} \mathrm{C}$ for $1970-71$ to $1979-80 ;\left\langle T_{\mathrm{s}}\right\rangle=-2.1^{\circ} \mathrm{C}$ for $1980-81$ to $1989-90 ;\left\langle T_{\mathrm{s}}\right\rangle=-1.0^{\circ} \mathrm{C}$ for $1990-91$ to $1996-97$. From 1970 to 1990 there was only one month with positive mean temperatures; in the 1990 s mean temperatures $\geq 0^{\circ} \mathrm{C}$ were observed for ten months. Particularly warm were the summers of 1992-93 $\left(+0.2^{\circ} \mathrm{C}\right)$ and $1994-95\left(+0.6^{\circ} \mathrm{C}\right)$. These observations are in agreement with the warming trend observed on the western side of the Antarctic Peninsula (King, 1994; Vaughan and Doake, 1996). During warm summers the infiltration of meltwater into cracks and crevasses intensifies the fracturing process. The freezing of the water in the crevasses is responsible for further reducing the dynamic stability of the ice mass. In addition to the negative impact of the warm temperatures on the surface mass balance, fracturing is a crucial factor for ice-shelf disintegration (Hughes, 1983).

\section{CONGLUSIONS}

In accordance with the behaviour of small ice shelves on the west coast of the Antarctic Peninsula (Vaughan and Doake, 1996), the northern LIS has retreated during recent decades which are characterised by increasing air temperatures. Nevertheless, the rapidity of the final break-up of the two northernmost sections was unexpected. The observations suggest that ice shelves, after a period of more or less constant retreat due to negative mass balance, may reach a critical limit at which minor disturbances may result in rapid collapse.

Table 3. Change of snow surface height SH $\left(\mathrm{cm} \mathrm{a}^{-1}\right)$, relating to the bottom of the stakes, at the transect south of Gray Nunatak for six periods between October 1980 and October 1996. The location of the stakes is shown in Figure 6

\begin{tabular}{ccccccc}
\hline Stakes & $1980-82$ & $1982-84$ & $1984-88$ & $1988-91$ & $1991-94$ & 199496 \\
\hline S1, 3 & +6 & +34 & +36 & +11 & -12 & -20 \\
S5 & +12 & +42 & +28 & +20 & -2 & -12 \\
S8, 9 & -10 & +38 & +31 & +22 & +7 & -12 \\
S13, 14, 15 & - & +51 & +38 & $+19(1988-94)$ & & - \\
\hline
\end{tabular}


If the warming trend continues, major retreat is likely within the next few years for the section of LIS north of Jason Peninsula. From mass-balance estimates it can be concluded that several centuries would be needed to build up the northern LIS if cooler climate conditions return. This implies that the warm period of the last few decades is without precedent for at least several centuries.

\section{ACKNOWLEDGEMENTS}

The ERS-1 SAR data were made available by the European Space Agency (ESA) for ERS experiment AO2.A101. The temperature data for Marambio station were provided by Servicio Meteorológico Nacional, Fuerza Area, Argentina. This work is a contribution to Austrian Science Fund (FWF) project No. 10709-GEO and to the LIS project of Instituto Antártico Argentino, Dirección Nacional del Antártico.

\section{REFERENGES}

Cooper, A. P. R. 1997. Historical observations of Prince Gustav Ice Shelf. Polar Rec., 33(187), 285-294.
Doake, C. S. M. 1982. State of balance of the ice sheet in the Antarctic Peninsula. Ann. Glaciol., 3, 77-82.

Frolich, R. M. 1992. The surface mass balance of the Antarctic Peninsula ice sheet. In Morris, E. M., ed. The contribution of Antarctic Peninsula ice to sea level rise. Cambridge, British Antarctic Survey, 3-9. (Ice and Climate Special Report 1.)

Hughes, T. 1983. On the disintegration of ice shelves: the role of fracture. $\mathcal{F}$. Glaciol., 29 (101), 98-117.

Jacobs, S. S., H. H. Hellmer, C. S. M. Doake, A. Jenkins and R. M. Frolich. 1992. Melting of ice shelves and the mass balance of Antarctica. 7. Glaciol., 38(130), 375-387.

King, J. C. 1994. Recent climate variability in the vicinity of the Antarctic Peninsula. Int. 7. Climatol., 14(4), 357-369.

Reece, A. 1950. The ice of Crown Prince Gustav Channel, Graham Land, Antarctica. 7. Glaciol., 1 (8), 404-409.

Rott, H., P. Skvarca and T. Nagler. 1995. Recent changes of Larsen Ice Shelf, Antarctic Peninsula, unveiled by ERS-1. Revista SELPER, 11 (12), 46-50.

Rott, H., P. Skvarca and T. Nagler. 1996. Rapid collapse of northern Larsen Ice Shelf, Antarctica. Science, 271 (5250), 788-792.

Skvarca, P. 1993. Fast recession of the northern Larsen Ice Shelf monitored by space images. Ann. Glaciol., 17, 317-321.

Skvarca, P. 1994. Changes and surface features of the Larsen Ice Shelf, Antarctica, derived from Landsat and Kosmos mosaics. Ann. Glaciol., 20, 6-12.

Vaughan, D. G. and C. S. M. Doake. 1996. Recent atmospheric warming and retreat of ice shelves on the Antarctic Peninsula. Nature, 379(6563), 328-331. 